\title{
UJI REGRESI LINIER BERGANDA UNTUK MENENTUKAN KONDISI DAN RELASI JUMLAH ARANG DENGAN TEMPERATUR DAN WAKTU PADA PROSES KARBONISASI GAMBUT
}

\author{
Harijanto Soetjijo* dan Rasyid Iskandar* \\ Harijanto Soetjijo dan Rasyid Iskandar, Uji Regresi Linier Berganda untuk menentukan \\ kondisi dan relasi Jumlah Arang dengan Temperatur dan Waktu pada Proses Karbonisasi \\ Gambut, RISET - Geologi dan Pertambangan Jilid 15 No.2 Tahun 2005, pp. 19 - 28, 3 \\ tabel.
}

Sari: Percobaan karbonisasi dengan menggunakan gambut yang berasal dari daerah Tulung Salapan, Sumatera Selatan telah dilakukan di laboratorium. Serangkaian data-data mengenai waktu; temperatur karbonisasi; dan jumlah arang/char-yield hasil karbonisasi gambut telah dikumpulkan. Untuk menelaah hubungan antara char-yield dengan temperatur dan waktu karbonisasi serta kondisi proses karbonisasi gambut tersebut suatu metoda uji regresi linier berganda digunakan dan diwakili oleh persamaan: $Z=f(t e m p$, waktu $)=\{99,310-0,113 *$ temperatur $-0,390 *$ waktu $\}$. Pengujian keberartian terhadap persamaan diatas dengan analisa variansi uji $\mathrm{F}$ memperlihatkan bahwa nilai $\mathrm{F}=92,725$ yang ternyata lebih besar dari nilai $\mathrm{F}_{\text {tabel }}$ dengan tarap signifikansi $5 \%$ atau $\mathrm{F}_{0,05}(2 ; 39)$ yang besarnya adalah 3,23. Hal ini berarti bahwa hipotesa nol $/ \mathrm{H}_{\mathrm{o}}$ ditolak dan menunjukkan bahwa pengaruh temperatur dan waktu karbonisasi terhadap char-yield memang ada dan diakui dalam proses, beserta pula persamaan diatas (model) memenuhi persyaratan yang diinginkan sehingga dapat digunakan. Pengujian keberartian dari masing-masing koefisien regresi dengan uji t menunjukkan nilai t untuk masing-masing koefisien adalah sebagai berikut: $\mathrm{tb}_{\mathrm{o}}=21,454 ; \mathrm{tb}_{1}=-10,394$; dan $\mathrm{tb}_{2}=-8,799$. Dengan tarap signifikansi $\alpha=5 \%$ dan dengan derajat kebebasan $\mathrm{v}=(\mathrm{n}-\mathrm{k})$; maka nilai $\mathrm{t}_{\text {tabel }}$ atau $\mathrm{t}$ $\alpha,(n-k)$ atau $t_{0,05,(39)}$ adalah 1,679. Hal diatas mempunyai arti bahwa: ada pengaruh positip dari $X$ atau $Y$ terhadap $Z$; pengaruh negatip dari $X$ terhadap $Z$ dan pengaruh negatip dari $\mathrm{Y}$ terhadap Z. Selanjutnya hasil perhitungan menghasilkan nilai $r_{\mathrm{xz}, \mathrm{y}}=-0,857$, yang menunjukkan besarnya sumbangan (share) kuatnya hubungan dari $\mathrm{X}$ terhadap $\mathrm{Z}$ dengan mengandaikan $\mathrm{Y}$ tetap/konstan. Nilai $\mathrm{r}_{\mathrm{yz}, \mathrm{x}}=-0,816$ menunjukkan besarnya share dari $\mathrm{Y}$ terhadap Z dengan X tetap. Nilai Koefisien Korelasi Pearson (r) atau Koefisien Moment Product (multiple R) adalah 0,909 yang menunjukkan besarnya derajat keeratan dari hubungan antara variabel char-yield terhadap waktu dan temperatur karbonisasi. Perhitungan juga memperlihatkan bahwa nilai Koefisien Determinasi $\left(\mathrm{R}\right.$ square $=\mathrm{r}^{2}$ ) adalah 0.826 , yang berarti bahwa $82,6 \%$ besarnya char-yield dipengaruhi oleh waktu dan temperatur karbonisasi, sedangkan sisanya sebesar $17,4 \%$ ditentukan oleh faktor atau variabel lainnya. Nilai $\mathrm{r}^{2}$ yang disesuaikan (adjusted $\mathrm{R}$ square) adalah 0,817 yang berarti besarnya pengaruh waktu dan temperatur terhadap char-yield yang sesungguhnya adalah sebesar $81,7 \%$. Hasil interpretasi juga memperlihatkan bahwa proses karbonisasi gambut terbaik adalah proses karbonisasi pada temperatur $350^{\circ} \mathrm{C}$ dengan waktu karbonisasi selama 25 menit. Hal ini didasarkan pada hasil perhitungan yang menunjukkan bahwa pada percobaan tersebut besarnya char-yield prediksi adalah 50,01\% dibandingkan dengan $50,14 \%$ char-yield percobaan yang berarti bahwa nilai residualnya adalah sebesar $0,13 \%$.

Abstract: A carbonization experiment using peat from Tulung Salapan area, South of Sumatera has been carried out in laboratory. A series of data that covers time; temperature

\footnotetext{
* Pusat Penelitian Geoteknologi - LIPI
} 
of carbonization; and char-yield produced from the peat carbonization have been collected. To examine the relation of char-yield with temperature and time of carbonization and the condition of the peat carbonization a double linier regression test method is used and represented by the equation: $\mathrm{Z}=\mathrm{f}$ (temp, time) $=\{99,310-$ $0,113 *$ temperature $-0,390 *$ time $\}$. Hypothesis test for the equation is conducted using Ftest for variancy analysis shows the value of $F=92,725$ is greater than the value of $F_{\text {tabel }}$ at the $5 \%$ significance level or $F_{0,05}(2 ; 39)=3,23$. This represents that the null hypothesis $/ \mathrm{H}_{\mathrm{o}}$ is rejected which means that the effect of temperature and time of carbonization to the char-yield is present and should be taken into account in the process, besides that, it also means that equation (model) can fulfilled the condion needs so that it can be used. The hypothesis test for the regression coefficient using t-test shows the value of each coefficient is as followed: $\mathrm{tb}_{\mathrm{o}}=21,454 ; \mathrm{tb}_{1}=-10,394$; and $\mathrm{tb}_{2}=-8,799$. At the significance level $\alpha=5 \%$ and the freedom degree $v=(n-k)$; the value of $t_{\text {tabel }}$ or $t_{\alpha,(n-k)}$ or $t$ $0,05,(39)$ is 1,679 . It means that there is a positive effect from $X$ or $Y$ to $Z$; a negative effect from $X$ to $Z$ and negative effect from $Y$ to $Z$. Moreover, the calculation shows the value of $r_{x z, y}=-0,857$, which represents the relation sharing of $X$ to $Z$ if $Y$ is constant. The value of $r_{y z, x}=-0,816$ represents the relation sharing of $Y$ to $Z$ if $X$ is constant.

The Pearson Correlation Coefficient ( $r$ ) or Moment Product Coefficient (multiple R) is 0,909 which represents the degree of relation between char-yield with time and temperature of carbonization. The calculation also shows the Determination Coefficient ( $R$ square $=r^{2}$ ) is 0.826 , which means that $82,6 \%$ of char yield is affected by time and temperature of carbonization, meanwhile the remaining $17,4 \%$ is determined by the other factors or variables. The value of adjusted $r^{2}$ (R square) is 0,817 which represents the real effect of time and temperature to the char-yield is $81,7 \%$. The interpretation also show that the optimal peat carbonization is the experiment conducted at $350^{\circ} \mathrm{C}$ with 25 minutes of carbonization. This is based on the result of the calculation which shows that in that experiment the predicted char-yield is $50,01 \%$ compared with the $50,14 \%$ of char-yield experiment which means that the residual value yield of the experiment is $0,13 \%$.

\section{PENDAHULUAN}

Dalam proses pembuatan karbon aktif dari gambut, tahapan awal yang dilakukan adalah mengubah gambut menjadi arang/char atau lebih populernya disebut tahapan karbonisasi. Produk yang dihasilkan dari tahapan karbonisasi adalah arang dan penilaian keberhasilan proses karbonisasi tersebut adalah besarnya jumlah arang yang dihasilkan dari proses. Banyaknya arang yang dihasilkan tergantung dari berbagai faktor/variabel baik yang berkaitan dengan peralatan yang digunakan seperti jenis tungku yang digunakan; ukuran/kapasitas tungku, jenis bahan mentah atau faktor/variabel operasional dari proses karbonisasi itu sendiri seperti tinggi temperatur yang digunakan; waktu karbonisasi dll. Berkaitan dengan proses karbonisasi gambut yang dilakukan di laboratorium Pusat Penelitian Geoteknologi LIPI, ada dua variabel utama yang menjadi penentu keberhasilan proses karbonisasi yaitu waktu karbonisasi dan temperatur. Interaksi yang terjadi antara hasil perolehan yang berupa arang (char-yield) dengan waktu dan temperatur dari karbonisasi merupakan hal-hal yang ingin diketahui. Dalam tulisan ini, hubungan yang terkait antara variabel jumlah arang dengan waktu dan temperatur karbonisasi akan ditelaah dan diuji kebenarannya serta dihitung nilainya. Untuk tujuan tersebut, suatu metoda uji statistik yang berdasarkan pada model regresi linier berganda dipergunakan. Hasil studi ini dapat memberikan gambaran yang lebih jelas mengenai interaksi yang terjadi dalam proses karbonisasi gambut sehingga nilai atau relasi antara hasil perolehan (char-yield) yang berupa arang/char dengan waktu dan temperatur dari karbonisasi dapat dikuantifisir. Selain itu, tulisan ini juga ditujukan untuk memperlihatkan penggunaan metoda uji statistik pada umumnya dan regresi linier berganda pada khususnya dalam usaha untuk menentukan kondisi optimal dari suatu proses karbonisasi gambut. 


\section{Latar Belakang Teori}

Pada dasarnya suatu model regresi linier berganda digunakan untuk menduga atau meramalkan nilai variabel bergantung (dependent) $\mathrm{Y}$ berdasarkan hasil pengukuran dari beberapa variabel bebas $\mathrm{X}_{1}, \mathrm{X}_{2}, \ldots . . \mathrm{X}_{\mathrm{n}}$.

Persamaan untuk peramalan dapat diperoleh dengan menggunakan prosedur kuadrat terkecil (least square) terhadap data-data yang terkait dan kemudian dihitung koefisien regresinya.

Secara umum sampel random berukuran $n$ dari populasi itu dapat dituliskan sebagai berikut: $\left\{\left(X_{1 \mathrm{i}}, \mathrm{X}_{2 \mathrm{i}}, \ldots . . \mathrm{X}_{1 \mathrm{ri}}, \mathrm{Y}_{\mathrm{i}}\right) ; \mathrm{I}=1,2, \ldots \ldots . \mathrm{n}\right\}$, dimana nilai $\mathrm{Y}_{\mathrm{i}}$ adalah nilai yang berasal dari suatu variabel random $Y_{\mathrm{i}}$.

Diasumsikan persamaan linier yang berlaku adalah sebagai berikut:

$\mu \mathrm{Y} \mid \mathrm{X}_{1}, \mathrm{X}_{2}, . . \mathrm{X}_{\mathrm{r}}=\beta_{0}+\beta_{1} \cdot \mathrm{X}_{1}+\beta_{2} \cdot \mathrm{X}_{2}+\ldots+\beta_{\mathrm{r}} \cdot \mathrm{X}_{\mathrm{r}}$.

Dalam hal ini, $\beta_{0}, \beta_{1}, \ldots . \beta_{\mathrm{r}}$ adalah parameter yang harus diduga dari data. Dengan melambangkan nilai dugaannya oleh $b_{0}, b_{1}$, $\ldots . ., b_{\mathrm{r}}$ maka persamaan regressi dari sampel dapat ditulis dalam bentuk:

$$
\mathrm{Y}=\mathrm{b}_{0}+\mathrm{b}_{1} \cdot \mathrm{X}_{1}+\mathrm{b}_{2} \cdot \mathrm{X}_{2}+\ldots \ldots \ldots+\mathrm{b}_{\mathrm{r}} \cdot \mathrm{X}_{\mathrm{r}}
$$

Dalam studi ini, hanya ada dua variabel bebas sehingga persamaan regresinya menjadi:

$$
\mathrm{Y}=\mathrm{b}_{0}+\mathrm{b}_{1} \cdot \mathrm{X}_{1}+\mathrm{b}_{2} \cdot \mathrm{X}_{2}
$$

dan setiap pengamatan memenuhi hubungan:

$$
\begin{gathered}
Y_{i}=Y+e_{i} \text { atau } \\
Y_{i}=b_{0}+b_{1} \cdot X_{1 i}+b_{2} \cdot X_{2 i}+e_{1 i}
\end{gathered}
$$

Nilai dugaan kuadart terkecil $b_{0}, b_{1}$ dan $b_{2}$ dapat diperoleh dengan menyelesaikan persamaan linier simultan

$$
\text { n. } b_{0}+b_{1} \cdot \sum X_{1 i}+b_{2} \cdot \sum X_{2 i}=\sum Y_{i}
$$

$\mathrm{b}_{0} \cdot \sum \mathrm{X}_{1 \mathrm{i}}+\mathrm{b}_{1} \cdot \sum \mathrm{X}_{1 \mathrm{i}}^{2}+\mathrm{b}_{2} \cdot \sum \mathrm{X}_{1 \mathrm{i}} \cdot \mathrm{X}_{2 \mathrm{i}}=\sum \mathrm{X}_{1 \mathrm{i}} \cdot \mathrm{Y}_{\mathrm{i}}$ $b_{0} . \sum X_{2 i}+b_{1} \cdot \sum X_{1 i} \cdot X_{2 i}+b_{2} \cdot \sum X_{2 i}^{2}=\sum X_{2 i} . Y_{i}$

Sistim persamaan linier tersebut dapat diselesaikan dengan berbagai cara antara lain dengan kaidah Cramer (sistim determinan) atau sistim matriks (eliminasi Gauss).

\section{Pengujian Keberartian}

Selanjutnya dilakukan pengujian keberartian/ signifikansi terhadap hasil dari analisa data tersebut. Pengujian keberartian model dilakukan dengan analisa variansi/ragam dengan uji-F, dimana nilai $F$ hasil perhitungan akan dibandingkan dengan nilai $\mathrm{F}$ tabel. Apabila $\mathrm{F}$ hasil perhitungan atau $\mathrm{F}_{\text {hitung }}>\mathrm{F}_{\text {tabel }}$ maka hipotesa nol $\left(\mathrm{H}_{\mathrm{o}}\right)$ ditolak, sebaliknya bila $\mathrm{F}_{\text {hitung }} \leq \mathrm{F}_{\text {tabel }}$ maka $\mathrm{H}_{\mathrm{o}}$ diterima. Selanjutnya nilai taraf signifikansi ditentukan yaitu $\alpha=5 \%$, dengan derajat kebebasan $\mathrm{v}=(\mathrm{k}-1)$; $(\mathrm{n}-\mathrm{k})$.

Untuk pengujian keberartian masing-masing koefisien regresi digunakan uji-t. Hasil dari pengamatan yang berupa nilai $\mathrm{t}$ untuk masingmasing koefisien $\left(\mathrm{tb}_{\mathrm{o}} ; \mathrm{tb}_{1} ; \mathrm{tb}_{2}\right)$ dibandingkan dengan $\mathrm{t}_{\text {tabel }}$ atau $\mathrm{t}_{\alpha,(\mathrm{n}-\mathrm{k}) \text {. }}$

\section{Hubungan antara Variabel.}

Untuk menentukan besarnya hubungan antara masing-masing variabel maka dilakukan penentuan koefisien korelasi yang didapat dari hubungan antara variabel char-yield dengan waktu dan temperatur seperti Koefisien Korelasi Pearson (r) atau Koefisien Moment Product (multiple R); Koefisien Determinasi (R square = $\mathrm{r}^{2}$ ) dan nilai $\mathrm{r}^{2}$ yang disesuaikan (adjusted $\mathrm{R}$ square).

\section{EKSPERIMEN KARBONISASI GAMBUT}

\section{Peralatan dan Pelaksanaan Karbonisasi}

Tungku yang digunakan adalah sebuah tungku/furnace merk Stuart Scientic. Alat ini mempunyai ruang pembakar yang berukuran panjang $41 \mathrm{~cm}$; lebar $18 \mathrm{~cm}$ dan tinggi $13 \mathrm{~cm}$. Tungku pembakar ini dijalankan dengan aliran listrik dengan spesifikasi: tegangan 220v/240v; frekwensi $50 \mathrm{~Hz}$ dan daya listrik yang dibutuhkan 7000 watt.

Temperatur furnace dapat diatur secara otomatis dengan selang $50^{\circ} \mathrm{C}$ dan suhu tertinggi yang dapat dicapai adalah $1500^{\circ} \mathrm{C}$. Waktu pembakaran dapat diset dengan waktu selang 5 menit. 


\section{Kondisi Eksperimen}

Karbonisasi dilakukan pada temperatur yang berbeda yaitu: $350^{\circ} \mathrm{C} ; 400^{\circ} \mathrm{C}$ dan $450^{\circ} \mathrm{C}$ dengan waktu karbonisasi bervariasi dari: 20 menit; 25 menit; 30 menit ; 35 menit; 40 menit; 45 menit dan 50 menit.

Berdasarkan kombinasi antara temperatur dan waktu karbonisasi seperti diatas maka jumlah eksperimen karbonisasi yang dilakukan adalah sebanyak 42 buah.

\section{Proses Karbonisasi}

Proses karbonisasi gambut yang dilakukan pada studi ini terbagi menjadi dua tahap berikut:

- Tahap pengeringan: proses dimulai dengan melakukan pengeringan terhadap conto gambut yang berasal dari lapangan. Proses pengeringan gambut dilakukan dengan cara menjemur gambut dibawah sinar matahari sampai gambut tersebut kering.

- Tahap karbonisasi: Kemudian setelah dikeringkan gambut tersebut dikarbonisasi dengan menggunakan tungku pembakar dengan kondisi seperti tersebut diatas.

\section{Gambut}

Gambut yang diproses diperoleh dari daerah Tulung Salapan, Sumatera Selatan.

Gambut berwarna hitam kecoklatan, termasuk pada tahapan moulding sebelum peatification, meskipun sisa-sisa tanaman masih diketemukan. Gambut yang berasal dari lapangan dikeringkan dengan cara menjemurnya dibawah panas matahari. Setelah kering, gambut diaduk secara merata dan diambil dengan jumlah tertentu untuk ditimbang sesuai dengan jumlah yang dikehendaki.

Setelah gambut ditimbang, gambut dimasukkan kedalam tungku dengan menggunakan sebuah wadah yang terbuat dari kaleng. Temperatur tungku disetel pada suhu yang diinginkan dan proses karbonisasi dilakukan dengan waktu yang telah disetel. Setelah waktu karbonisasi dilalui maka wadah berisi conto dikeluarkan dan kemudian didinginkan pada temperature ruang. Setelah dingin, isi wadah yang berupa arang serta abu yang merupakan hasil karbonisasi dikeluarkan.

Arang dipisahkan dari abunya dan kemudian arang hasil pembakaran gambut ditimbang kembali. Berdasarkan perbedaan berat arang hasil proses karbonisasi dan gambut asal maka besarnya jumlah char-yield atau arang dapat dihitung.

\section{HASIL DAN PEMBAHASAN}

Hasil eksperimen karbonisasi gambut dapat dilihat pada Tabel 1 dibawah ini.

Tabel 1 ini memperlihatkan kondisi temperatur; waktu eksperimen; berat gambut sebelum dikarbonisasi; berat arang/char sebagai produk dan $\%$ perolehan/yield.

\section{Uji Regresi Linier Berganda terhadap Hasil Karbonisasi}

\section{Persamaan regresi yang digunakan}

Berdasarkan pengamatan terhadap data-data yang tercantum pada Tabel 1 diatas, maka suatu bentuk persamaan umum yang memperlihatkan relasi antara yield yang diperoleh dengan waktu dan temperatur karbonisasi telah dihasilkan.

Persamaan tersebut adalah sebagai berikut:

$$
\begin{gathered}
\mathrm{Z}=\text { Char-Yield }=\mathrm{f}(\text { temp., waktu }) \\
=\mathrm{b}_{0}+\mathrm{b}_{1} \text {. temperatur }+\mathrm{b}_{2} \text {. waktu }
\end{gathered}
$$

Atau dijabarkan lebih lanjut sebagai berikut:

$$
\mathrm{Z}=\mathrm{f}\left(\mathrm{X}_{1}, \mathrm{X}_{2}\right)=\mathrm{b}_{0}+\mathrm{b}_{1} \cdot \mathrm{X}_{1}+\mathrm{b}_{2} \cdot \mathrm{X}_{2}
$$

Berdasarkan analisa data-data tersebut (lihat Tabel 1) maka persamaan yang diperoleh adalah:

$$
\begin{gathered}
Z=\mathrm{f}(\text { temp, waktu }) \\
=99,310-0,113 * \text { temperatur }-0,390 * \text { waktu }
\end{gathered}
$$

Dengan standar error masing-masing adalah:

$$
\text { 4,629; 0,011; dan 0,044. }
$$

Jadi dari persamaan diatas diperoleh:

$$
b_{0}=99,310 ; b_{1}=-0,113 ; \text { dan } b_{2}=-0,390
$$


RISET - Geologi dan Pertambangan Jilid 15 No.2 Tahun 2005

Tabel 1. Percobaan karbonisasi gambut dan hasil arang yang diperoleh.

\begin{tabular}{|c|c|c|c|c|c|}
\hline No. & $\begin{array}{c}\text { Temperatur } \\
\left({ }^{\circ} \mathrm{C}\right)\end{array}$ & $\begin{array}{l}\text { Waktu } \\
\text { (menit) }\end{array}$ & $\begin{array}{c}\text { Berat gambut } \\
\text { (gram) }\end{array}$ & $\begin{array}{c}\text { Berat arang } \\
\text { (gram) }\end{array}$ & $\begin{array}{c}\text { Hasil perolehan } \\
\text { /yield }(\%)\end{array}$ \\
\hline 1 & 350 & 20 & 40,26 & 22,18 & 55,09 \\
\hline 2 & 350 & 20 & 40,35 & 19,43 & 48,15 \\
\hline 3 & 350 & 25 & 40,40 & 20,02 & 49,55 \\
\hline 4 & 350 & 25 & 40,33 & 20,22 & 50,14 \\
\hline 5 & 350 & 30 & 40,45 & 20,17 & 49,86 \\
\hline 6 & 350 & 30 & 40,49 & 20,12 & 49,61 \\
\hline 7 & 350 & 35 & 40,30 & 19,25 & 47,77 \\
\hline 8 & 350 & 35 & 40,33 & 19,00 & 47,11 \\
\hline 9 & 350 & 40 & 40,10 & 17,94 & 44,74 \\
\hline 10 & 350 & 40 & 40,12 & 17,96 & 44,77 \\
\hline 11 & 350 & 45 & 40,17 & 17,65 & 43,94 \\
\hline 12 & 350 & 45 & 40,16 & 17,90 & 44,57 \\
\hline 13 & 350 & 50 & 40,33 & 16,86 & 41,80 \\
\hline 14 & 350 & 50 & 40,25 & 17,30 & 42,98 \\
\hline 15 & 400 & 20 & 40,21 & 18,93 & 47,08 \\
\hline 16 & 400 & 20 & 40,41 & 20,41 & 50,51 \\
\hline 17 & 400 & 25 & 41,81 & 19,53 & 46,71 \\
\hline 18 & 400 & 25 & 41,54 & 20,56 & 49,49 \\
\hline 19 & 400 & 30 & 40,73 & 15,32 & 37,61 \\
\hline 20 & 400 & 30 & 40,92 & 16,20 & 39,59 \\
\hline 21 & 400 & 35 & 41,19 & 14,74 & 35,78 \\
\hline 22 & 400 & 35 & 41,36 & 15,32 & 37,04 \\
\hline 23 & 400 & 40 & 41,68 & 14,80 & 35,51 \\
\hline 24 & 400 & 40 & 41,16 & 14,40 & 34,98 \\
\hline 25 & 400 & 45 & 40,10 & 13,30 & 33,17 \\
\hline 26 & 400 & 45 & 40,05 & 13,52 & 33,76 \\
\hline 27 & 400 & 50 & 39,85 & 10,98 & 27,55 \\
\hline 28 & 400 & 50 & 38,11 & 12,54 & 32,90 \\
\hline 29 & 450 & 20 & 40,15 & 15,71 & 39,13 \\
\hline 30 & 450 & 20 & 40,14 & 15,82 & 39,41 \\
\hline 31 & 450 & 25 & 40,15 & 15,29 & 38,08 \\
\hline 32 & 450 & 25 & 40,13 & 15,31 & 38,15 \\
\hline 33 & 450 & 30 & 40,11 & 14,89 & 37,12 \\
\hline 34 & 450 & 30 & 40,19 & 15,10 & 37,57 \\
\hline 35 & 450 & 35 & 40,18 & 14,18 & 35,24 \\
\hline 36 & 450 & 35 & 40,07 & 14,20 & 35,44 \\
\hline 37 & 450 & 40 & 40,79 & 13,98 & 34,27 \\
\hline 38 & 450 & 40 & 40,69 & 13,83 & 33,99 \\
\hline 39 & 450 & 45 & 40,39 & 14,22 & 35,21 \\
\hline 40 & 450 & 45 & 40,18 & 13,96 & 34,74 \\
\hline 41 & 450 & 50 & 40,56 & 13,14 & 32,40 \\
\hline 42 & 450 & 50 & 40,75 & 12,85 & 31,48 \\
\hline
\end{tabular}

\section{Pengujian Keberartian (Uji-F dan Uji-t)}

\section{Uji-F}

Pengujian keberartian terhadap persamaan di atas telah dilakukan dengan menggunakan analisa variansi dengan uji $\mathrm{F}$. Hasil pengujian dengan uji $\mathrm{F}$ tersebut menghasilkan nilai $\mathrm{F}$ hasil perhitungan sebesar 92,725. Dengan nilai taraf signifikansi $\alpha=5 \%$, dengan derajat kebebasan $\mathrm{v}$ $=(\mathrm{k}-1) ;(\mathrm{n}-\mathrm{k}) ;$ dimana pada studi ini $\mathrm{n}=42$ dan $\mathrm{k}$ $=3$ maka dari tabel akan diperoleh nilai $\mathrm{F}_{\text {tabel }}$ atau $\mathrm{F}_{\alpha}\{(\mathrm{k}-1) ;(\mathrm{n}-\mathrm{k})\}$ yaitu $\mathrm{F}_{0,05}(2 ; 39)=3,23$. 
Nilai $\mathrm{F}$ perhitungan ini akan dibandingkan dengan nilai $\mathrm{F}$ tabel, dimana apabila $\mathrm{F}$ hasil perhitungan atau $F_{\text {hitung }} \geq F_{\text {tabel }}$ maka hipotesa nol $\left(\mathrm{H}_{\mathrm{o}}\right)$ ditolak, sebaliknya bila $\mathrm{F}_{\text {hitung }} \leq \mathrm{F}_{\text {tabel }}$ maka $\mathrm{H}_{\mathrm{o}}$ diterima.

Jadi dari hasil diatas nilai $\mathrm{F}=92,725>\mathrm{F}_{0,05}$ $(2 ; 39)=3,23$. Hal ini berarti bahwa hipotesa null atau $\mathrm{H}_{\mathrm{o}}$ ditolak sehingga dapat ditarik kesimpulan bahwa dalam studi ini pengaruh temperatur dan waktu karbonisasi terhadap charyield memang ada dan diakui. Selain itu persamaan diatas (model) memenuhi persyaratan yang diinginkan sehingga dapat digunakan.

\section{Uji-t}

Uji-t dipergunakan untuk melakukan pengujian keberartian dari masing-masing koefisien regresi. Dari hasil pengamatan dan perhitungan (lihat Tabel 1), diperoleh nilai $\mathrm{t}$ untuk masing-masing koefisien yaitu sebagai berikut: $\mathrm{tb}_{\mathrm{o}}=21,454 ; \mathrm{tb}_{1}=-10,394 ;$ dan $\mathrm{tb}_{2}=$ 8,799. Nilai-nilai dari $\mathrm{tb}_{\mathrm{o}} \mathrm{tb}_{1}$ dan $\mathrm{tb}_{2}$ di atas dibandingkan dengan $\mathrm{t}$ tabel atau $\mathrm{t}{ }_{\alpha,(\mathrm{n}-\mathrm{k})}$ dimana untuk melakukan hal tersebut dipergunakan hipotesa nol $\left(\mathrm{H}_{\mathrm{o}}\right)$. Dengan tarap signifikansi $\alpha=$ $5 \%$, dengan derajat kebebasan $\mathrm{v}=(\mathrm{n}-\mathrm{k})$; maka diperoleh bahwa nilai $\mathrm{t}_{\alpha,(\mathrm{n}-\mathrm{k})}=\mathrm{t}_{0,05,(39)}=1,679$. Jadi jelas bahwa:

$$
\begin{gathered}
\mathrm{tb}_{\mathrm{o}}=21,454>\mathrm{t}_{\alpha,(\mathrm{n}-\mathrm{k})}=\mathrm{t}_{0,05,(39)}=1,679 \\
\mathrm{tb}_{1}=-10.394<-\mathrm{t}_{\alpha,(\mathrm{n}-\mathrm{k})}=-\mathrm{t}_{0,05,(39)}=-1,679 \\
\mathrm{tb}_{2}=-8.799<-\mathrm{t}_{\alpha,(\mathrm{n}-\mathrm{k})}=-\mathrm{t}_{0,05,(39)}=-1,679
\end{gathered}
$$

Hal diatas mempunyai arti bahwa:

Untuk $\mathrm{tb}_{\mathrm{o}}$ menolak $\mathrm{H}_{\mathrm{o}}$ artinya ada pengaruh positip dari $\mathrm{X}$ atau $\mathrm{Y}$ terhadap $\mathrm{Z}$;

Untuk tb $_{1}$ menolak $\mathrm{H}_{\mathrm{o}}$ artinya ada pengaruh negatip dari $\mathrm{X}$ terhadap $\mathrm{Z}$ dan

Untuk $\mathrm{tb}_{2}$ menolak $\mathrm{H}_{\mathrm{o}}$ artinya ada pengaruh negatip dari Y terhadap Z.

\section{Hubungan antara X; Y dan Z}

Selanjutnya besarnya sumbangan (share) kuatnya hubungan dari $\mathrm{X}$ terhadap $\mathrm{Z}$ dengan mengandaikan Y tetap/konstan dan Y terhadap Z dengan $X$ tetap, dari hasil perhitungan diperoleh:

$$
\text { nilai } r_{x z, y}=-0,857 \text { dan } r_{y z, x}=-0,816 \text {. }
$$

Nilai $r_{x z, y}=-0,857$ menunjukkan besarnya sumbangan (share) kuatnya hubungan dari $\mathrm{X}$ terhadap $\mathrm{Z}$ dengan mengandaikan $\mathrm{Y}$ tetap/konstan. Nilai $\mathrm{r}_{\mathrm{yz}, \mathrm{x}}=-0,816$ menunjukkan besarnya share dari $\mathrm{Y}$ terhadap $\mathrm{Z}$ dengan $\mathrm{X}$ tetap.

\section{Koefisien Korelasi}

Koefisien korelasi yang didapat dari hubungan antara variabel char-yield dengan waktu dan temperatur ditunjukkan oleh keifisienkoefisien berikut:

Koefisien Korelasi Pearson (r) atau Koefisien Moment Product (multiple R) yang diperoleh adalah 0,909.

Koefisien Moment Product (multiple R) sebesar 0,909 menyatakan besarnya derajat keeratan hubungan antara variabel yield terhadap waktu dan temperatur karbonisasi.

Dilain pihak nilai Koefisien Determinasi ( $R$ square $=r^{2}$ ) yang diperoleh adalah 0,826 . Nilai $r^{2}$ $=0,826$ menyatakan bahwa $82,6 \%$ besarnya yield ditentukan oleh pengaruh waktu dan temperatur karbonisasi, sedangkan sisanya sebesar 17,4\% ditentukan oleh faktor atau variabel lainnya.

Adapun hasil perhitungan menunjukkan bahwa nilai $\mathrm{r}^{2}$ yang disesuaikan (adjusted $\mathrm{R}$ square) adalah 0,817 . Nilai $\mathrm{r}^{2}$ yang disesuaikan sebesar 0,817 menunjukkan besarnya pengaruh waktu dan temperatur terhadap char-yield yang sesungguhnya adalah sebesar $81,7 \%$.

Secara singkat persamaan regresi yang digunakan dan hasil perhitungannya dapat dlihat pada Tabel 2.

\section{Penentuan Kondisi Proses Karbonisasi}

Nilai dari char-yield dan kaitannya dengan waktu serta temperatur telah disusun dan hasilnya dapat dilihat pada Tabel 3 .

Perbandingan antara char-yield hasil percobaan laboratorium dan hasil perhitungan

Nilai char-yield dari hasil percobaan laboratorium

Suatu proses karbonisasi dapat diukur tingkat keberhasilannya berdasarkan jumlah arang yang dihasilkan atau char-yield (Figueiredo J.L.; Moulijn J.A, 1986). 
Tabel 2. Persamaan regresi proses karbonisasi gambut.

\begin{tabular}{|c|c|}
\hline Persamaan regresi & $\mathrm{Z}=\mathrm{f}(\mathrm{temp}$, waktu $)=99,310-0,113 *$ temperatur $-0,390 *$ waktu \\
\hline Standart error & 4,$629 ; 0,011 ;$ dan 0,044 \\
\hline Jumlah data karbonisasi & 42 \\
\hline taraf signifikansi $\alpha$ & $5 \%$ \\
\hline \multicolumn{2}{|l|}{ Uji F } \\
\hline $\mathrm{F}_{\text {hitung }}$ & 92,725 \\
\hline $\mathrm{F}_{\text {tabel }}=\mathrm{F}_{0,05}(2 ; 39)$ & 3,23 \\
\hline \multicolumn{2}{|l|}{ Uji t } \\
\hline $\mathrm{tb}_{\mathrm{o}}$ & 21,454 \\
\hline $\mathrm{tb}_{1}$ & $-10,394$ \\
\hline $\mathrm{tb}_{2}$ & $-8,799$ \\
\hline $\mathrm{t}_{\alpha,(\mathrm{n}-\mathrm{k})}=\mathrm{t}_{0,05,(39)}$ & 1,679 \\
\hline Koef. Korelasi Pearson (r) & 0,909 \\
\hline \multicolumn{2}{|l|}{ Koefisien Moment Product (multiple R) } \\
\hline Koefisien Determinasi $\left(\mathrm{R}\right.$ square $\left.=\mathrm{r}^{2}\right)$ & 0,826 \\
\hline Koefisien Determinasi adjusted (R square) & 0,817 \\
\hline
\end{tabular}

Pengamatan pada data-data char-yield hasil percobaan pada Tabel 3 menunjukkan bahwa ada tiga buah data char-yield yang relatip lebih tinggi dibandingkan dengan data char-yield lainnya yaitu dari percobaan no. 1 dengan char-yield sebesar 55,09\%; percobaan no. 16 dengan charyield sebesar $50,51 \%$ dan percobaan no. 4 dengan char-yield sebesar 50,14\% (secara berurutan dari yang tertinggi nilainya). Percobaan lainnya menghasilkan char-yield yang lebih rendah sehingga tidak akan diikut sertakan dalam pembahasan.

Percobaan no. 1 yang dilakukan pada temperatur $350^{\circ} \mathrm{C}$ dengan waktu percobaan 20 menit menghasilkan perolehan jumlah char-yield sebesar 55,09\%. Nilai char-yield tertinggi berikutnya adalah $50,51 \%$ yang diperoleh dari percobaan no. 16 yang dilakukan pada temperatur $400^{\circ} \mathrm{C}$ dengan waktu 20 menit. Percobaan ketiga adalah percobaan no 4 yang dilaksanakan pada temperatur $350^{\circ} \mathrm{C}$ dengan waktu percobaan selama 25 menit yang menghasilkan nilai char-yield sebesar 50,14\%.

Jadi berdasarkan hasil perolehan jumlah char-yield tersebut maka percobaan no. 1 yang dilakukan dengan temperatur $350^{\circ} \mathrm{C}$ dengan waktu percobaan 20 menit merupakan percobaan yang paling berhasil. Percobaan dengan temperatur $400^{\circ} \mathrm{C}$ dengan waktu 20 menit (percobaan no. 16) merupakan percobaan terbaik berikutnya atau berada pada urutan kedua sedangkan percobaan dengan temperatur $350^{\circ} \mathrm{C}$ dengan waktu percobaan selama 25 menit (percobaan no. 4) merupakan percobaan yang berada pada urutan ketiga.

Nilai char-yield dari hasil perhitungan regresi linier

Dilain pihak, hasil penilaian atau perhitungan statistik dengan metoda regresi linier berganda menunjukkan bahwa perolehan char-yield dari ketiga percobaan tersebut adalah: 51,96\%; $46,31 \%$ dan $50,01 \%$ berturut-turut (no. 1; 16 dan 4).

Perhitungan selanjutnya menunjukkan bahwa beda atau selisih nilai yang diperoleh dari perbedaan nilai char-yield hasil percobaan di laboratorium/pengamatan dengan nilai char-yield hasil perhitungan menggunakan persamaan regresi adalah sebesar $3,13 \% ; 4,20 \%$ dan $0,13 \%$ berturut-turut. 
Berdasarkan angka residual char-yield maka angka residual terkecil adalah $0,13 \%$ yang diperoleh pada percobaan no. 4. Angka residual yang lebih kecil menunjukkan bahwa percobaan tersebut relatip lebih efektip sehingga dalam hal ini dapat dikatakan bahwa percobaan dengan hasil yang lebih baik diperoleh pada percobaan dengan temperatur $350^{\circ} \mathrm{C}$ dengan waktu percobaan selama 25 menit yaitu percobaan no. 4 tersebut dibandingkan dengan percobaan no. 1 yang menjadi percobaan dengan urutan kedua dan terakhir adalah percobaan no. 16 .

Tabel 3. Nilai char-yield hasil percobaan dan char-yield hasil perhitungan.

\begin{tabular}{|c|c|c|c|c|c|}
\hline No & $\begin{array}{c}\text { Temperatur } \\
\left({ }^{\circ} \mathrm{C}\right)\end{array}$ & $\begin{array}{l}\text { Waktu } \\
\text { (menit) }\end{array}$ & $\begin{array}{c}\text { Char-Yield } \\
\text { percobaan (\%) }\end{array}$ & $\begin{array}{c}\text { Char-Yield } \\
\text { hasil perhitungan (\%) }\end{array}$ & Residu char-yield (\%) \\
\hline 1 & 350 & 20 & 55,09 & 51,96 & 3,13 \\
\hline 2 & 350 & 20 & 48,15 & 51,96 & $-3,81$ \\
\hline 3 & 350 & 25 & 49,55 & 50,01 & $-0,40$ \\
\hline 4 & 350 & 25 & 50,14 & 50,01 & 0,13 \\
\hline 5 & 350 & 30 & 49,86 & 48,06 & 1,80 \\
\hline 6 & 350 & 30 & 49,61 & 48,06 & 1,55 \\
\hline 7 & 350 & 35 & 47,77 & 46,11 & 1,66 \\
\hline 8 & 350 & 35 & 47,11 & 46,11 & 1,00 \\
\hline 9 & 350 & 40 & 44,74 & 44,16 & 0,58 \\
\hline 10 & 350 & 40 & 44,77 & 44,16 & 0,61 \\
\hline 11 & 350 & 45 & 43,94 & 42,21 & 1,73 \\
\hline 12 & 350 & 45 & 44,57 & 42,21 & 2,36 \\
\hline 13 & 350 & 50 & 41,80 & 40,26 & 1,54 \\
\hline 14 & 350 & 50 & 42,98 & 40,26 & 2,72 \\
\hline 15 & 400 & 20 & 47,08 & 46,31 & 0,77 \\
\hline 16 & 400 & 20 & 50,51 & 46,31 & 4,20 \\
\hline 17 & 400 & 25 & 46,71 & 44,36 & 2,35 \\
\hline 18 & 400 & 25 & 49,49 & 44,36 & 5,13 \\
\hline 19 & 400 & 30 & 37,61 & 42,41 & $-4,80$ \\
\hline 20 & 400 & 30 & 39,59 & 42,41 & $-2,82$ \\
\hline 21 & 400 & 35 & 35,78 & 40,46 & $-4,68$ \\
\hline 22 & 400 & 35 & 37,04 & 40,46 & $-3,42$ \\
\hline 23 & 400 & 40 & 35,51 & 38,51 & $-3,00$ \\
\hline 24 & 400 & 40 & 34,98 & 38,51 & $-3,53$ \\
\hline 25 & 400 & 45 & 33,17 & 36,56 & $-3,39$ \\
\hline 26 & 400 & 45 & 33,76 & 36,56 & $-2,80$ \\
\hline 27 & 400 & 50 & 27,55 & 34,61 & $-7,06$ \\
\hline 28 & 400 & 50 & 32,90 & 34,61 & $-1,71$ \\
\hline 29 & 450 & 20 & 39,13 & 40,66 & $-1,53$ \\
\hline 30 & 450 & 20 & 39,41 & 40,66 & $-1,25$ \\
\hline 31 & 450 & 25 & 38,08 & 38,71 & $-, 0,63$ \\
\hline 32 & 450 & 25 & 38,15 & 38,71 & $-0,56$ \\
\hline 33 & 450 & 30 & 37,12 & 36,76 & 0,36 \\
\hline 34 & 450 & 30 & 37,57 & 36,76 & 0,81 \\
\hline 35 & 450 & 35 & 35,24 & 34,81 & 0,43 \\
\hline 36 & 450 & 35 & 35,44 & 34,81 & 0,63 \\
\hline 37 & 450 & 40 & 34,27 & 32,86 & 1,41 \\
\hline 38 & 540 & 40 & 33,99 & 32,86 & 1,13 \\
\hline 39 & 450 & 45 & 35,21 & 30,91 & 4,30 \\
\hline 41 & 450 & 45 & 34,74 & 30,91 & 3,83 \\
\hline 41 & 450 & 50 & 32,40 & 28,96 & 3,44 \\
\hline 42 & 450 & 50 & 31,48 & 28,96 & 2,52 \\
\hline
\end{tabular}


Yang jelas berdasarkan hasil di atas ada perbedaan interpretasi mengenai penentuan kondisi percobaan berdasarkan nilai char-yield.

Percobaan yang dinilai terbaik berdasarkan perolehan char-yield hasil percobaan dapat berbeda dengan hasil perhitungan uji regresi linier berganda. Metoda uji regresi linier berganda mempunyai kemampuan lebih untuk melakukan penilaian karena uji regresi mampu menghitung nilai residual sehingga penentuan relasi antara nilai char-yield dengan temperatur dan waktu percobaan karbonisasi dapat dilakukan secara lebih terperinci. Pengamatan dan analisa terhadap data-data laboratorium atau percobaan secara konvensional biasanya sudah cukup memadai, meskipun pengaruh subjektif kadang-kadang sulit dihindari sedangkan dengan uji statistik, pengujian dapat dilakukan secara lebih mendetail dan objektif sehingga dapat dipertanggung jawabkan secara lebih baik pula.

\section{KESIMPULAN DAN SARAN}

1. Hasil penelaahan data-data hasil percobaan karbonisasi gambut dari daerah Tulung Salapan, Sumatera Selatan menunjukkan bahwa persamaan regresi linier berganda yang memperlihatkan relasi antara char-yield dengan waktu dan temperatur karbonisasi yang dihasilkan adalah:

$$
\begin{gathered}
\mathrm{Z}=\mathrm{f}(\text { temp, waktu })=99,310-0,113 * \\
\text { temperatur }-0,390 * \text { waktu }
\end{gathered}
$$

Dengan standar error masing-masing adalah:

$$
\text { 4,629; 0,011; dan 0,044. }
$$

dimana:

$$
\mathrm{b}_{0}=99,310 ; \mathrm{b}_{1}=-0,113 ; \text { dan } \mathrm{b}_{2}=-0,390 \text {. }
$$

2. Hasil pengujian uji $\mathrm{F}$ menghasilkan nilai $\mathrm{F}$ hasil perhitungan sebesar 92,725, yang lebih besar dari nilai $\mathrm{F}_{\text {tabel }}$ atau $\mathrm{F}_{0,05}(2 ; 39)$ yaitu 3,23 . Hal ini berarti bahwa hipotesa nol atau $\mathrm{H}_{\mathrm{o}}$ ditolak sehingga dapat ditarik kesimpulan bahwa pengaruh temperatur dan waktu karbonisasi terhadap char-yield memang ada dan diakui. Selain itu persamaan di atas (model) memenuhi persyaratan yang diinginkan sehingga dapat digunakan.
3. Uji-t dipergunakan untuk melakukan pengujian keberartian dari masing-masing koefisien regresi. Dari hasil pengamatan data-data di atas, diperoleh nilai $\mathrm{t}$ untuk masing-masing koefisien yaitu sebagai berikut:

$\mathrm{tb}_{\mathrm{o}}=21,454 ; \mathrm{tb}_{1}=-10,394 ;$ dan $\mathrm{tb}_{2}=-8,799$.

Nilai-nilai dari $\mathrm{tb}_{\mathrm{o}}$; tb $\mathrm{b}_{1}$ dan $\mathrm{tb}_{2}$ di atas dibandingkan dengan $t_{\text {tabel }}$ atau $t_{\alpha,(n-k) \text {, dimana }}$ hasilnya adalah:

$$
\begin{aligned}
& \mathrm{tb}_{\mathrm{o}}=21,454>\mathrm{t}_{\alpha,(\mathrm{n}-\mathrm{k})}=\mathrm{t}_{0,05,(39)}=1,679 \\
& \mathrm{tb}_{1}=-10.394<-\mathrm{t}_{\alpha,(\mathrm{n}-\mathrm{k})}=-\mathrm{t}_{0,05,(39)}=-1,679 \\
& \mathrm{tb}_{2}=-8.799<-\mathrm{t}_{\alpha,(\mathrm{n}-\mathrm{k})}=-\mathrm{t}_{0,05,(39)}=-1,679
\end{aligned}
$$

Hal di atas mempunyai arti bahwa:

Untuk $\mathrm{tb}_{\mathrm{o}}$ menolak $\mathrm{H}_{\mathrm{o}}$ artinya ada pengaruh positip dari $\mathrm{X}$ atau $\mathrm{Y}$ terhadap $\mathrm{Z}$; untuk $\mathrm{tb}_{1}$ menolak $\mathrm{H}_{\mathrm{o}}$ artinya ada pengaruh negatip dari $\mathrm{X}$ terhadap $\mathrm{Z}$ dan untuk $\mathrm{tb}_{2}$ menolak $\mathrm{H}_{\mathrm{o}}$ artinya ada pengaruh negatip dari $\mathrm{Y}$ terhadap Z.

4. Besarnya sumbangan (share) atau kuatnya hubungan dari $\mathrm{X}$ dan $\mathrm{Y}$ terhadap $\mathrm{Z}$ dinyatakan berdasarkan dari hasil perhitungan yang memperlihatkan bahwa nilai $r_{x z, y}=-0,857$ dan $r_{y z, x}=-0,816$. Nilai $\mathrm{r}_{\mathrm{xz}, \mathrm{y}}=-0,857$ menunjukkan besarnya sumbangan (share) kuatnya hubungan dari X terhadap $\mathrm{Z}$ dengan mengandaikan $\mathrm{Y}$ tetap/konstan.

Nilai $r_{\mathrm{yz}, \mathrm{x}}=-0,816$ menunjukkan besarnya share dari $Y$ terhadap $Z$ dengan $X$ tetap.

5. Koefisien Korelasi Pearson (r) atau Koefisien Moment Product (multiple R) yang diperoleh adalah 0,909, yang menyatakan besarnya derajat keeratan hubungan antara variabel char-yield terhadap waktu dan temperatur karbonisasi adalah sebesar 90,9\%. Dilain pihak nilai Koefisien Determinasi ( $R$ square $=r^{2}$ ) yang diperoleh adalah 0,826 . Nilai $r^{2}=0,826$ menyatakan bahwa $82,6 \%$ besarnya charyield ditentukan oleh pengaruh waktu dan temperatur karbonisasi, sedangkan sisanya sebesar $17,4 \%$ ditentukan oleh faktor atau variabel lainnya. Adapun hasil perhitungan menunjukkan bahwa nilai $\mathrm{r}^{2}$ yang 
disesuaikan (adjusted $\mathrm{R}$ square) adalah 0,817 . Nilai $\mathrm{r}^{2}$ yang disesuaikan sebesar 0,817 menunjukkan besarnya pengaruh waktu dan temperatur terhadap char-yield yang sesungguhnya adalah sebesar $81,7 \%$.

6. Berdasarkan hasil percobaan karbonisasi di laboratorium yang dinyatakan dengan jumlah char-yield maka percobaan no. 1 yang dilakukan dengan temperatur $350^{\circ} \mathrm{C}$ dengan waktu percobaan 20 menit merupakan percobaan yang paling baik dengan angka char-yield sebesar 55,09\%. Percobaan dengan temperatur $400^{\circ} \mathrm{C}$ dengan waktu 20 menit (percobaan no. 16) merupakan percobaan terbaik berikutnya atau berada pada urutan kedua dengan angka char-yield sebesar 50,51\% sedangkan percobaan dengan temperatur $350^{\circ} \mathrm{C}$ dengan waktu percobaan selama 25 menit (percobaan no. 4) merupakan percobaan yang berada pada urutan ketiga dengan angka char-yield sebesar 50,14\%. Dilain pihak, hasil penilaian atau perhitungan statistik dengan metoda regresi linier berganda menunjukkan bahwa hasil perhitungan perolehan char-yield dari ketiga percobaan tersebut adalah: 51,96\%; 46,31\% dan 50,01\% berturut-turut (no. 1; 16 dan 4). Perhitungan selanjutnya menunjukkan bahwa beda atau selisih nilai yang diperoleh dari perbedaan nilai char-yield hasil percobaan di laboratorium/pengamatan dengan nilai char-yield hasil perhitungan menggunakan persamaan regresi adalah sebesar $3,13 \% ; 4,20 \%$ dan $0,13 \%$ berturutturut. Berdasarkan angka residual char-yield tersebut maka angka residual terkecil adalah $0,13 \%$ yang diperoleh pada percobaan no. 4 . Angka residual yang lebih kecil menunjukkan bahwa percobaan tersebut relatip lebih efektip sehingga dalam hal ini dapat dikatakan bahwa percobaan dengan hasil yang lebih baik diperoleh pada percobaan dengan temperatur $350^{\circ} \mathrm{C}$ dengan waktu percobaan selama 25 menit, yaitu percobaan no. 4 tersebut dibandingkan dengan percobaan no. 1 yang menjadi percobaan dengan urutan kedua terbaik dan berikutnya adalah percobaan no. 16 .

\section{UCAPAN TERIMA KASIH}

Dalam kesempatan ini, para penulis ingin mengungkapkan rasa terima kasih kepada berbagai pihak di bawah ini yang telah membantu dalam pelaksanaan studi sehingga dapat berjalan sesuai dengan jadwal yang telah ditentukan dan tidak mengalami hambatan yang berarti. Ucapan terima kasih, kami tujukan kepada: Kepala Puslit Geoteknologi LIPI, Pimpro dan bendaharawan serta bagian keuangan Puslit Geoteknologi LIPI, Teknisi Laboratorium Kimia Puslit Geoteknologi serta Pemda Sumatera Selatan dan aparat yang terkait.

\section{DAFTAR PUSTAKA}

Banker, R., Charnes, A., Cooper, W., 1984. Some models for technical and scale inefficiencies in data development analysis. Management Science 30; no. 9; hal. 1078-1092.

Bansal, R.C., et al., 1988. Activated Carbon. Marcell Dekker Inc. New York.

Cook, R.D., Weisberg, S., 1999. Applied Regression Including Computing and Graphics. Wiley, New York.

Deithorn, R.T., Mazzoni, A.F., 1986. Activated Carbon. What it is. How it works. Water Technology, vol. 5, no. 8, hal. 26-29.

Figueiredo J.L.; Moulijn J.A, 1986. Carbon and coal gasification. Martinus Nijhoff Publishers. NATO ASI Series.

Hassler, J.W., 1963. Activated Carbon. Chemical Publishing Company Inc., New York.

Smisek, M., Cerny, S.M., 1970. Activated Carbon. Manufacture, properties and applications. Elsevier, Amsterdam. 